\title{
Physiological and Hematological Profiles among the Highlanders of Mount Kinabalu
}

\author{
Norlizah Abdul Hamid, Raja Mohamad Firhad Raja Azidin, Sarimah Ismail, \\ Nagoor Meera Abdullah \\ Faculty of Sports Science and Recreation, \\ Universiti Teknologi MARA, 40150 Shah Alam, Selangor, Malaysia \\ norli144@salam.uitm.edu.my
}

\begin{abstract}
Previous studies show that people residing at the highlands had the potential in physical endurance. The main objective of this study was to obtain the physiological and haematological profile of the highlanders residing at Mount Kinabalu. 27 male and four female porters and guides with age ranged from 17 to 51 years old working at the Sabah National Park voluntarily participated in the study. Anthropometric measurement, physiological attributes and hematological components were measured. Even though the participants had high haemoglobin levels, their $\mathrm{VO}_{2}$ max were below the average level. Follow-up studies should consider assessment of other physiological factors at higher altitudes.

Keywords: highlanders; endurance; physiological attributes; hematological components

eISSN 2398-4279 @ 2018. The Authors. Published for AMER ABRA cE-Bs by e-International Publishing House, Ltd., UK. This is an open access article under the CC BY-NC-ND license (http://creativecommons.org/licenses/bync-nd/4.0/). Peer-review under responsibility of AMER (Association of Malaysian Environment-Behaviour Researchers), ABRA (Association of Behavioural Researchers on Asians) and CE-Bs (Centre for EnvironmentBehaviour Studies), Faculty of Architecture, Planning \& Surveying, Universiti Teknologi MARA, Malaysia.

DOI: https://doi.org/10.21834/ajqol.v3i9.84
\end{abstract}




\subsection{Introduction}

Studies show that in native altitude residents, a significant increase of red cell volume as well as hemoglobin concentration and hematocrit value are at above altitudes of $2500 \mathrm{~m}$. Some investigation of altitude training found that the increase in red cell volume amount is $10 \%$ on average. This is only slightly more than after sea training in non-athletes (8\%). Other studies found that increase in hemoglobin between sea level resident and high level resident is about $12 \%$. The increase in hemoglobin occurs after approximately $4-7$ days of altitude exposure (Casas et al., 2000).

Probably it is necessary to realize that to benefit from altitude acclimatization, one must stay in that altitude for a long time. Any benefit of altitude acclimatization is lost quickly by those who only stay in high altitudes or simulated condition for a short amount of time (Villafuerte et al, 2004).

The Kinabalu Park (1,563.8 m) at the base of Mount Kinabalu (4,095.2 m) was selected as the location for this study. The natives living at this altitude for most of their lives work as guides and porters. Petite aged-women carry baskets of canned foods and drinks even gas tanks from Timpohon Gate $(1,866.4 \mathrm{~m})$ on their backs and climb the mountain to Laban Rata $(3,272.7 \mathrm{~m})$. The weights these people may have to carry could reach up to $80 \mathrm{~kg}$ since there may be times where the guides may need to carry climbers who are unable to complete the climb.

Keyl et.al. (2003) reported that the natives of the Andes living permanently at an altitude of $4,300 \mathrm{~m}$ had hematocrit levels of more than $65 \%$ as compared to the typical college-aged males of $42 \%$ (Powers and Howley, 2004). People residing at altitudes above $4,540 \mathrm{~m}$ in Morococha, Peru showed hemoglobin levels of $211 \mathrm{~g}^{-1-1}$ in contrast to the average $156 \mathrm{~g}^{-1}$ of the sea-level residents in Lima (Powers and Howley, 2004).

Previous studies also showed that $\mathrm{VO}_{2}$ max values were higher in these people than those residing at sea levels. Hence, do people residing at altitudes have physiological potentials in endurance sports? What explains the surprising outstanding performance of Kipchoge Keino's who had spent his childhood at altitude similar to Mexico City $(1,500 \mathrm{~m})$ in the1968 Olympic Games?

This study embarks on the following objectives i.e., to investigate the physiological, hematological and fitness profile of the residents living at altitudes of Mount Kinabalu, and to explore the potential of the natives at high-altitudes of Mount Kinabalu in endurance sports and athletics.

Therefore, the sports agencies in Malaysia may have to explore and experiment with talents from various native and indigenous people throughout the country. Developmental and genetic factors may influence the components of the cardiorespiratory system that determines endurance performance. It is also believed that the cultural background of the society such as the residents of Mount Kinabalu, Bajau Laut, Senoi among others have great influences in making them potentials as future athletes of the country. 


\subsection{Literature Review}

As mentioned above, there are previous findings regarding the changes of blood concentrate during altitude training and exposure to the environment.

Extreme altitude presents an enormous physiological challenge to the human body because of severe oxygen deprivation. High climbs by mountaineers have stimulated much interest in the physiology of severe hypoxia. Norton reached over 8,500 m on Mt. Everest in 1924, but the summit was not attained without supplementary oxygen until 1978, the last $300 \mathrm{~m}$ took 54 years after Norton's attempt. This suggests that the summit at an altitude of $8,848 \mathrm{~m}$, was nearing the limit of human tolerance, and predictions based on maximal work levels measured at lower altitudes are consistent with this.

Adaptation to altitude is a relatively long process achieved by spending from few days to many weeks at high altitude. At high altitudes, a number of physiological responses occur. The main changes are ventilatory variations as early responses, and hematological changes with an increase in red blood cell, packed cell volume and hemoglobin concentration which are long term responses, that contribute to increasing the oxygen-carrying of the blood.

According to Wehrlin et al. (2006) "living high-training low" might be a way of improving physical performance, given that living at high altitude give rise to a series of advantageous physiological adaptations, mainly hematological, enough to elicit an increase in red blood cell mass while training at sea level maximizes training, improving performance. However, it is certainly a difficult procedure to implement.

The decrease in maximum oxygen consumption with increasing altitude could be due to a decrease in cardiac output or/and a decrease in oxygen extraction. At sea level, hemoglobin is about $96 \%$ to $98 \%$ saturated with oxygen. However, at 2,300 m and $4,000 \mathrm{~m}$ saturations fall to $88 \%$ and $71 \%$ respectively (Casas, 2000).

In men, the normal value for hematocrit is $45 \%$ to $61 \%$, and 13 to $21 \mathrm{~g} / \mathrm{dL}$ for hemoglobin, whilst $41 \%$ to $56 \%$ hematocrit and 12 to $19 \mathrm{~g} / \mathrm{dL}$ hemoglobin in women. However, a study by Vasquez R (2001) on 1,934 healthy, young (aged 15 to $29 \mathrm{yr}$ ) male and female residents of Potosí, Bolivia ( $4000 \mathrm{~m}$ ), showed the male hematocrit averaged $52.7 \%$ and hemoglobin averaged $17.3 \mathrm{~m} / \mathrm{dL}$. The female values of hematocrit and haemoglobin were $48.3 \%$ and $15.8 \mathrm{~g} / \mathrm{dL}$, respectively. These data indicated that hematocrit and hemoglobin values for both men and female were outside the normal range.

Powers and Howley (2006) also mentioned that this desaturation of arterial blood at altitude affects more than the maximum oxygen consumption. The desaturation of blood in the body will trigger the release of the hormone erythropoietin (EPO) that stimulates red blood cell production. Erythropoietin is used as a part of therapy for those who undergo chemotheraphy or dialysis. The hormone stimulates red blood cell production to reduce the chance of anemia. However, at altitude the body's response or adaptation to the above situation is to produce additional red blood cells to compensate for the desaturation of hemoglobin at altitude. It can be seen from the difference in people residing at altitude to sea level residents; Sea level : $156 \mathrm{~g}$. L-1 times $1.34 \mathrm{ml} 02 . \mathrm{g}^{-1}$ at $98 \%$ saturation $=206 \mathrm{ml}$. . L-1. At $4,540 \mathrm{~m}: 211 \mathrm{~g}$. L-1 times $1.34 \mathrm{ml} 02 \cdot \mathrm{g}^{-1}$ at $81 \%$ saturation $=224 \mathrm{ml}$. L-1.

On Mount Everest, the speed of ascent was very high ( $5600 \mathrm{~m}$ of altitude gain in 6 days). Conventional expeditions which took normally around 12 to 32 days are necessary to reach 
safely of the same altitude. It is found that pre-acclimatization seems to have triggered efficient mechanisms which allowed climbers to save 1 to 3 weeks of time in mountains conditions.

\subsection{Methodology}

This research applied the convenience non-random sampling method in selecting the participants for the study and was limited to volunteered porters and guides. 27 male guides and four female porters participated in this study. They were the guides and porters working at the Sabah National Park with working experience between one to ten years at the park.

Anthropometric measurement consisted of age, body height, weight, waist to hip ratio (WHR), skinfold measurements, whilst the hematological measurement included the resting heart rate together with systolic and diastolic blood pressures. Other measurements include hemoglobin level and maximum blood lactate at the end of the bleep test. The physiological attributes were assessed through scores from the sit and reach test for flexibility, handgrip strength using the hand grip dynamometer, standing broad jump for lower body strength, maximum curl-up for abdominal muscular endurance and bleep test for aerobic capacity determination.

All data were compiled and analyzed using the SPSS version 21.0.

\subsection{Findings and Analysis 11AN bold}

27 male guides and four female porters voluntarily participated in this study. The findings are as the following:

Table 1: Anthropometric data

\begin{tabular}{|lcc|}
\hline Anthropometric data & Males $(\mathrm{n}=27)$ & Females $(\mathrm{n}=4)$ \\
Age (years) & $30.7 \pm 9.1$ & $41.6 \pm 5.9$ \\
Height (cm) & $161.2 \pm 6.3$ & $149 \pm 7.4$ \\
Weight (kg) & $60.6 \pm 6.8$ & $48.6 \pm 6.4$ \\
BMI (kg.m $\left.{ }^{-2}\right)$ & $23.3 \pm 2.3$ & $21.9 \pm 1.9$ \\
Waist (cm) & $78.0 \pm 6.9$ & $67 \pm 4.2$ \\
Hip (cm) & $91.8 \pm 5.0$ & $89.3 \pm 4.7$ \\
WHR (waist:hip ratio) & $0.85 \pm 1.4$ & $0.75 \pm 0.02$ \\
Sum of skinfolds (mm) & $33.7 \pm 11.8$ & $33.5 \pm 8.3$ \\
\hline
\end{tabular}


Table 1 shows the values of mean and standard deviations for the participants' anthropometric data. The mean age was $30.7 \pm 9.1$ years for males and $41.6 \pm 5.9$ years for females, whilst the mean height and weight was $161.2 \pm 6.3 \mathrm{~m}$ and $60.6 \pm 6.8 \mathrm{~kg}$, respectively for males. For females, the mean height was $149 \pm 7.4 \mathrm{~m}$ and the mean weight was $48.6 \pm$ $6.4 \mathrm{~kg}$. The mean body mass index was $23.3 \pm 2.3 \mathrm{~kg}$. m-2 and $21.9 \pm$ $1.9 \mathrm{~kg} \cdot \mathrm{m}^{-2}$, for males and females, respectively. This indicated that all participants fall under the category of normal healthy weight.

Male participants had mean waist circumference of $78.0 \pm 6.9 \mathrm{~cm}$, and female participants had $67 \pm 4.2 \mathrm{~cm}$. As for the hip circumference, males had a mean of $91.8 \pm 5.0$ $\mathrm{cm}$ and females had $89.3 \pm 4.7 \mathrm{~cm}$. This brings the waist to hip ratio for males to $0.85 \pm 1.4$ and $0.75 \pm 0.02$ for females. Sum of skinfolds shows similar results of $33.7 \pm 11.8 \mathrm{~mm}$ and $33.5 \pm 8.3 \mathrm{~mm}$ for males and females, respectively.

Table 2: Hematological data

\begin{tabular}{|lcc|}
\hline Hematological data & Males $(\mathrm{n}=27)$ & Females $(\mathrm{n}=4)$ \\
Resting heart rate $\left(\mathrm{b} \cdot \mathrm{min}^{-1}\right)$ & $70.1 \pm 14.6$ & $57.5 \pm 6.6$ \\
Resting systolic $\mathrm{BP}(\mathrm{mmHG})$ & $129.6 \pm 14.5$ & $104 \pm 12.6$ \\
Resting diastolic BP $(\mathrm{mmHg})$ & $77.2 \pm 12.7$ & $66.3 \pm 7.9$ \\
Haemoglobin $\left(\mathrm{g} \cdot \mathrm{dL}^{-1}\right)$ & $16.7 \pm 1.3$ & $13.0 \pm 0.5$ \\
Maximum lactate & & \\
(mMole. $\left.\mathrm{L}^{-1}\right)$ & $12.1 \pm 3.0$ & $9.5 \pm 2.9$ \\
\hline
\end{tabular}

Table 2 shows the values of mean and standard deviations for the participants' hematological data. The mean resting heart rate was $70.1 \pm 14.6$ b. min $^{-1}$ for males and 57.5 $\pm 6.6 \mathrm{~b}_{\text {. } \mathrm{min}^{-1}}$ for females. The mean systolic blood pressure was $129.6 \pm 14.5 \mathrm{mmHg}$ and $104 \pm 12.6 \mathrm{mmHg}$, for males and females, respectively. Males had resting diastolic blood pressure of $77.2 \pm 12.7 \mathrm{mmHg}$, whilst females had $66.3 \pm 7.9 \mathrm{mmHg}$. As for the haemoglobin content, males had a higher level of $16.7 \pm 1.3 \mathrm{~g} . \mathrm{dL}^{-1}$ compared to females that had a mean of $13.0 \pm 0.5 \mathrm{~g} \cdot \mathrm{dL}^{-1}$.

Table 3 shows the values of mean and standard deviations for the participants' physiological attributes. The mean flexibility was $10.3 \pm 6.7 \mathrm{~cm}$ for males and $19.4 \pm 6.5 \mathrm{~cm}$ for females, whilst the mean right hand grip and left hand grip was $42.1 \pm 6.6 \mathrm{~kg}$ and $37.9 \pm 5.4 \mathrm{~kg}$, respectively for the males. For females, the mean right hand grip was $26.6 \pm 4.3 \mathrm{~kg}$ and left hand grip was $25.4 \pm 4.6 \mathrm{~kg}$. The mean standing broad jump score was

$2.1 \pm 0.2 \mathrm{~m}$ and $1.5 \pm 0.2 \mathrm{~m}$, for males and females, respectively. Male participants scored $27.6 \pm 9.0$ repetitions and females $21.5 \pm 4.7$ repetitions on the maximum curl-up.

As for $\mathrm{VO}_{2}$ max, males had a higher level of $32.0 \pm 6.1 \mathrm{~mL}^{\mathrm{kg}} \cdot \mathrm{min}^{-1}$ compared to females that had $27.5 \pm 1.4 \mathrm{~mL}$.kg. $\mathrm{min}^{-1}$. However, all participants fall under the category of below normal in relations to aerobic fitness. Maximum heart rate at the end of the bleep test showed that males achieved higher heart rate of $172.7 \pm 19.0 \mathrm{~b} \mathrm{~min}^{-1}$ than females of $151.8 \pm 27.0 \mathrm{~b}$. min- 
1. Similar pattern was shown with the maximum lactate where male participants had higher lactate level of $12.1 \pm 3.0 \mathrm{mMole}^{\mathrm{L}} \mathrm{-}^{1}$ than the females of $9.5 \pm 2.9 \mathrm{mMole} . \mathrm{L}^{-1}$.

Table 3: Physiological data

\begin{tabular}{|l|c|c|}
\hline & Males (n=27) & Females (n=4) \\
\hline Flexibility (cm) & $10.3 \pm 6.7$ & $19.4 \pm 6.5$ \\
\hline Hand grip- right (kg) & $42.1 \pm 6.6$ & $26.6 \pm 4.3$ \\
\hline Hand grip - left (kg) & $37.9 \pm 5.4$ & $25.4 \pm 4.6$ \\
\hline Standing broad jump (m) & $2.1 \pm 0.2$ & $1.5 \pm 0.2$ \\
\hline Curl-up (maximum) & $27.6 \pm 9.0$ & $21.5 \pm 4.7$ \\
\hline VO $_{2}$ max (mL.kg.min-1) & $32.0 \pm 6.1$ & $27.5 \pm 1.4$ \\
\hline Maximum heart rate (b.min $\left.{ }^{-1}\right)$ & $172.7 \pm 19.0$ & $151.8 \pm 27.0$ \\
\hline & & \\
\hline
\end{tabular}

\subsection{Discussion}

The mean body mass index was $23.3 \pm 2.3 \mathrm{~kg} . \mathrm{m}^{-2}$ and $21.9 \pm 1.9 \mathrm{~kg} \cdot \mathrm{m}^{-2}$, for males and females, respectively. This indicated that all participants fall under the category of normal healthy weight.

In this study, male participants had WHR of $0.85 \pm 1.4$, while female participants had $0.75 \pm$ 0.02. The World Health Organization (WHO) states that abdominal obesity is defined as a waist-hip ratio above 0.90 for males and above 0.85 for females. Therefore, all participants were in the normal healthy category. The sum of skinfolds showed similar results for male and female that also in the healthy range.

Resting blood pressures were in the normal range on average for all participants.

All participants had good flexibility. However, the males scored average on the standing broad jump while the females were below average which is indicative of the lower limb muscular power. However, they had average hand grip strengths. As for the haemoglobin content, males had a higher level of $16.7 \pm 1.3 \mathrm{~g} . \mathrm{dL}^{-1}$ compared to females that had a mean of $13.0 \pm 0.5 \mathrm{~g} . \mathrm{dL}^{-1}$. This is in agreeable to the study by by Vasquez $\mathrm{R}$ (2001) on 1,934 healthy, young (aged 15 to $29 \mathrm{yr}$ ) male and female residents of Potosí, Bolivia (4000 $\mathrm{m}$ ), showed the male hematocrit averaged $52.7 \%$ and hemoglobin averaged $17.3 \mathrm{~m} / \mathrm{dL}$. Values for female were $48.3 \%$ and $15.8 \mathrm{~g} / \mathrm{dL}$, respectively. This indicated the potential in endurance performance among the highlanders.

In the current study, males scored a higher $\mathrm{VO}_{2}$ max level of $32.0 \pm 6.1 \mathrm{~mL} . \mathrm{kg} . \mathrm{min}-$ ${ }^{1}$ compared to females that only had $27.5 \pm 1.4 \mathrm{~mL} . \mathrm{kg}$. $\mathrm{min}^{-1}$. Nevertheless, all participants fall under the category of below normal in relations to aerobic fitness. This could be due to the participants being unfamiliar with running. A study by Brothers MD et. al, 2010 on 55 military college men following a 46-week at moderate altitude (MA) suggested that complete 
acclimatization to $2210 \mathrm{~m}$ by former sea level (SL) may require lengthy physiological adaptation. MA participants had a significantly higher hemoglobin concentration $([\mathrm{Hb}]$, $+5.5 \%)$, hematocrit $(+2.8 \%)$, and serum ferritin $(+59.0 \%)$ and significantly lower sTfR ($11.4 \%)$ values than their SL peers. SL subjects had a significantly lower Vo2peak $(-5.9 \%)$, slower 1.5 - mile run time $(+5.4 \%)$, poorer running economy $(+6.6 \%)$, and lower composite physical fitness test score $(-13.9 \%)$ than MA subjects.

Maximum heart rates and maximum blood lactate recorded immediately at the end of the bleep test showed about $90 \%$ and $84 \%$ of the maximum respectively, for males and females. This indicated effort of near maximum during the test. However, they did not score well in the test as for the reason mentioned earlier.

\subsection{Conclusion}

This study was to in a way to give a head start in the study of altitude in Malaysia. The understanding of the influence of the cultural background towards the skill competencies of people living at altitudes of Mount Kinabalu in endurance-related sports should also be taken into consideration.

Based on the findings of this study, it is recommended that the sports agencies in Malaysia to conduct talent identification programme among the people residing at altitudes of Mount Kinabalu. In seeking for new athletes, The Ministry of Sports, The Ministry of Education, National Sports Council, Malaysia Schools Sports Council, need to carry out more sports competition at the district and state levels involving people residing at altitudes of Mount Kinabalu.

\section{Acknowledgement}

We would like to thank the Research Management Institute (RMI), UiTM for funding this study through the Excellence Fund, the management of Sabah National Park and the respective participants involved.

\section{References}

Adams G.M Exercise Physiology: Laboratory Manual. $4^{\text {th }}$ Edition,McGraw Hill (2002)

Alonso J.G., Richardson R.S., Saltin B. Exercising skeletal muscle blood flow in humans responds to reduction in arterial oxyhemoglobin, but not to altered free oxygen. Journal of Physiology. 530.2:331-341 (2001)

Brothers MD, Doan BK, Zupan MF, Wile AL, Wilber RL, Byrnes WC. Hematological and physiological adaptations following 46 weeks of moderate altitude residence. High Alt Med Biol. Fall;11(3):199-208 (2010).

Casas H., Casas M., Ricart A., Rama R., Ibanez J., Palacios L., Rodriguez F.A., Ventura J.L., Viscor G., Pages T. Effectiveness of Three Short Intermittent Hypobaric Hypoxia Protocols: Hematological Responses. Journal of Exercise Physiology Online, Vol 3, No 2, (2000) 
Gore C.J., Hopkins W.G., Burge C.M. Errors of measurement for blood volume parameters: a meta-analysis. Journal of Applied Physiology 99: 1745-1758 (2005)

Gunderson J.S., Chapman R.F., Levine B.D. "Living high-training low" altitude training improves sea level performance in male and female elite runners. Journal of Applied Physiology 91: 1113-1120 (2001)

Hall G.V., Calbet J.A.L., Sondergaard H., Saltin B. The re-establishment of the normal blood lactate response to exercise in humans after prolonged acclimatization to altitude. Journal of Physiology 536.3,pp.963-975 (2001)

Hamlin M.J., Hellemans J. Intermittent hypoxic training in endurance athletes. Research project paper No 02/22 (2003)

Powers S.K., Howley E.T. Exercise Physiology: Theory and Application to Fitness andPerformance. $5^{\text {th }}$ Edition. McGraw Hill. (2004)

Proffit F. Science in the 'Death Zone'. British Journal of Sports Medicine. Vol. 308. No. 5728, pp. 1541-1542 (2005) Rusko H.K. New aspects of altitude training. American Journals of Sports Medicine. 24:S48-S52 (1996)

Saunders P.U., Telford R.D, Pyne D.B., Cunningham R.B., Gore C.J., Hahn A.G., and Hawley J.A. Improved running economy in elite runners after 20 days of simulated moderate-altitude exposure. Journal of Applied Physiology 96: 931-937 (2004)

Townsend A.H., Kinsmn T.A., Chow C., McKenna M.J., Clark J.S.A., Auhghey R.J., Gore C.J., Hahn A.G., Nathan E. Effects of live high, train low hypoxic exposure on lactate metabolism in trained humans. Journal of Applied Physiology 96:517-525 (2004).

Villafuerte F.C., Cardenas R. Monge-C C. Optimal hemoglobin concentration and high altitude: a theoretical approach for Andean men at rest. Journal of Applied Physiology 96: 1581-1588 (2004)

Vásquez R, Villena M. Normal hematological values for healthy persons living at 4000 meters in Bolivia. High Altitude Medical Biology Fall:2(3):361-7 (2001)

Vogt M., Puntschart A., Geiser. J., Zuleger c., Billeter R., Hoppeler H. Molecular adaptation in human skeletal muscle to endurance training under simulated hypoxic conditions. Journal of Applied Physiology 91: 173-182 (2001)

West J.B. Barometric pressure on Mt.Everest: new data and physiological significance. Journal of Applied Physiology 86(3): 1062-1066 (1999)

Wehrlin J.P., Zuest P., Hallen J., Marti B. Live high-train low for 24 days increases hemoglobin mass and red cell volume in elite endurance athletes. Journal of applied Physiology 100: 1938-1945 (2006)

Wilber R.L. Current trends in altitude training. Journal of Sports Medicine 31: 249-265 (2001) 